\title{
Quantitative Detection of Cow Milk in Goat Milk Mixtures by Real-Time PCR
}

\author{
Yu-Kyung Jung, Deok-Young Jhon, Kanghwa Kim, and Youn-Ho Hong* \\ Department of Food and Nutrition, and Human Ecology Research Institute, Chonnam National University, \\ Gwangju 500-757, Korea
}

\begin{abstract}
The objective of this study was to develop a fluorogenic real-time PCR-based assay for detecting and quantifying amounts of cow milk in cow/goat milk mixtures or goat milk products. In order to quantify the exact amount of cow milk in cow/goat raw milk mixtures and commercial goat milk products, it was necessary to achieve quantitative extraction of total genomic DNA from the raw milk matrix. Both mammalian-specific PCR and cow-specific PCR were performed. A cow-specific 252 bp band obtained from the raw cow milk and raw goat milk mixtures, commercial goat milk, and two goat milk powders was identified, along with the relationship between the cow milk amount and band intensity of the electrophoresis image. The detection threshold was found to be $0.1 \%$. The expression of cow's $12 \mathrm{~S}$ rRNA in the cow/goat milk mixtures, commercial goat milk, and two goat milk powders was identified. The expression quantity of the milk 12S rRNA increased with increasing ratios of the cow/goat milk mixtures. Using these calibrated relative expression levels as a standard curve in the cow/goat raw milk mixtures, the contents of cow milk were $1.8 \%$ in the commercial goat milk, $9.6 \%$ in goat milk powder $\mathrm{A}$, and $11.6 \%$ in goat milk powder C. However, cow milk was not detected in goat milk powder B.
\end{abstract}

Key words: real-time polymerase chain reaction, quantitative detection, goat milk, cow milk

\section{Introduction}

It is well recognized that bovine (cow) milk and dairy products are nutritionally almost perfect animal foods. However, some bovine milk products are well known as allergy-inducing substances (Kotowicz et al., 2007).

Goat milk has been used as a health functional food in many countries. The chemical compositions of bovine milk and goat milk are different; goat milk contains less $\alpha_{\mathrm{s} 1}$-casein, which cannot be digested by babies, and $\beta$ lactoglobulin, which is a known allegen for some people. Goat milk has more nucleotides, immunoglobulins, polyamines, and taurine than bovine milk (McCane et al., 2007). Nutrient contents in goat milk are slightly lower than those in bovine milk, but the size of fat globules is much smaller than in bovine milk, which means better digestion. Furthermore, goat milk has more chlorine, bromine, and silicone than other animal milks (McCane et al., 2007).

\footnotetext{
*Corresponding author: Youn-Ho Hong, Department of Food and Nutrition, and Human Ecology Research Institute, Chonnam National University, Gwangju 500-757, Korea. Tel: 82-62-530-1333, Fax: 82-62-530-1339, E-mail: yhhong@, chonnam.ac.kr
}

In many countries, goat milk is much more expensive than bovine milk, and this could be a reason why people may fraudulently mix bovine milk with goat milk. Some cheeses have been made with bovine milk, sheep milk, and goat milk by mixing a minimum of $10 \%$, respectively (Mayer et al., 1997). In such cases, consumers do not trust products and some could suffer from allergy symptoms caused by bovine milk protein. Therefore, consumer demands for detailed information about food composition and ingredients have been increased (Mayer, 2005).

The protein in milk and dairy products has been analyzed by capillary electrophoresis (Molina et al. 1999), two-dimensional electrophoresis (Chianese et al., 1990), isoelectric focussing (Moio et al., 1990), HPLC (Ferreira and Cacote, 2003), ELISA (Anguita et al., 1997; Hurley, 2004), and so on. However, these methods are not optimal, but rather limiting because the proteins can be lost or degraded by heating, high pressure, and other operations during food processing (Bottero et al., 2003).

DNA in milk somatic cells is known to be very stable and therefore it is possible for species identification of milk using the polymerase-chain reaction (PCR) (Mafra et al., 2004).

Furthermore, real-time PCR is useful to quantify milk 
based on polymerization reaction (Mafra et al., 2008; Martinez et al., 2011; Takara, 2007).

Lee and Choi (2009) reported that rapid identification of bovine milk and goat milk in dairy products could be possible by Duplex PCR. Real-time PCR has been applied to exclude the false positive of conventional PCR, to reduce contamination rates, and to improve the reliability of results (Madani et al., 2005). Recently, real-time PCR assays were proposed to detect and quantify bovine milk in Mozzarella cheese (Lopparelli et al., 2007), and in Italian cheese (Mininni et al., 2009). Although there have been many reports about fraud detection of dairy products using PCR, few studies relating to rapid and sensitive methods have been reported for real-time PCR in commercial dairy products.

Therefore, in this study, we attempted to establish a more sensitive and correct real-time PCR method for quantification of bovine milk in commercial goat milk and goat milk powders.

\section{Materials and Methods}

\section{Material}

Raw goat milk was kindly provided by Rainbow Goat Milk Farm (Korea). Liquid cow milk and three kinds of goat milk powders were purchased from a local market. Cow milk was mixed with goat milk at ratios of $0.1,0.5$, $1,5,10,20$, and $39 \%$, respectively, to make standard samples and to quantify the bovine milk.

\section{Methods}

\section{Extraction of DNA and Quantification}

DNA was extracted using a G-spin genomic DNA extraction kit (INtRON Biotechnology, USA). The extracted DNA purity and concentration were measured in triplicate using a Nano Drop 1,000 Spectrophotometer (Thermo, Japan) at 230, 260, and $280 \mathrm{~nm}$.

Nucleotide primer and probe

In order to polymerize the $12 \mathrm{~S}$ rRNA gene, a cow specific primer basic sequence was applied using the same primer as Lopez-Calleja et al. (2007a) suggested: 12STAQMANBT. A goat specific primer (12STAQMANCH) basic sequence and mammalian specific primer (12STAQMANREVM2) were also used, and were the same primers as LopezCalleja et al. (2007b) reported. All applied forward primers were the same.

Primers and fluorogenic probes were adopted using Primer Express 2.0 software (Perkin Elmer-Applied Biosystems Division, USA) as recommended by Lopez-Callega et al. (2005).

The TaqMan probe method was used in this experiment with the 5' terminal employing fluorogenic 6-carboxyfluorescein (FAM) and the 3' terminal using the scavenging material 6-carboxy-tetramethylrhodamine (TAMRA), which was attached to a PCR reagent modified oligonucleotide (TaqMan probe). The primers and probes used in this experiment were made by Bioneer Co. (Korea). The basic sequences of the primers and probes are listed in Table 1.

\section{Real-time PCR}

For real-time PCR, a Rotor-Gene 6,000 (Corbett Research, Australia) was applied. The final volume of the reaction solution per sample was adjusted to $25 \mu \mathrm{L}$. The composition of the reaction solution was as follows: TaqMan Universal $2 \times 12.5 \mu \mathrm{L}$ of PCR master mix (Applied Biosystems, USA), $300 \mathrm{nM}$ of forward primer, $900 \mathrm{nM}$ of reverse primer, and a $200 \mathrm{nM}$ fluorescent probe (Bioneer Co., Korea), combined with sterilized distilled water and DNA matrix $(10 \mathrm{ng} / \mu \mathrm{L})$ and made to a total volume of 25 $\mu \mathrm{L}$; then real-time PCR was performed according to LopezCalleja et al. (2005). The following temperature and time program for TaqMan real-time PCR was applied: 2 min at $50^{\circ} \mathrm{C}, 10 \mathrm{~min}$ at $95^{\circ} \mathrm{C}$ as pre-denaturation, then 45 cycles with $15 \mathrm{~s}$ of denaturation at $95^{\circ} \mathrm{C}, 1 \mathrm{~min}$ of annealing at $60^{\circ} \mathrm{C}$, and $15 \mathrm{~s}$ of elongation at $72^{\circ} \mathrm{C}$.

\section{Reliability test of real-time PCR}

In order to check the sensitivity of the test method, stan-

Table 1. Primers and probes used in this study

\begin{tabular}{llc}
\hline \hline \multicolumn{1}{c}{ Gene } & \multicolumn{1}{c}{ Primer sequence 5' $\rightarrow 3^{\prime}$} & Product size \\
\hline $\begin{array}{l}\text { Forward primer } \\
(12 \text { STAQMANFWM })\end{array}$ & AAA GGA CTT GGC GGT GCTT & - \\
$\begin{array}{l}\text { Reverse primer } \\
\text { Cow (12STAQMANBT) }\end{array}$ & TGG TTT CAT AAT AAC TTT CGC GCT & $252 \mathrm{bp}$ \\
Goat (12STAQMANCH) & TGA CCT AAC GTC TTT ATG TGT GGT G & $171 \mathrm{bp}$ \\
Mammalian (12STAQMANREVM2) & GGG TTT GCT GAA GAT GGC G & $119 \mathrm{bp}$ \\
12SPROBE & FAM-TAGAGGAGCCTGTTCTATAATCGATAAACCCCG-TAMRA & - \\
\hline
\end{tabular}


dard curves for absolute quantification were obtained from plotting the log percentage of cow milk contained in each standard sample against the difference between threshold cycles (Cts) of the species-specific and reference reactions. Each amplification product aimed to perform absolute quantification included both test and standard samples.

For specificity tests, interactions between DNA templates of different species and primers were performed. Extracted DNA from raw milk was used as the standard sample. 12STAQMANCH and 12STAQMANBT from goat milk were reacted three times, respectively.

For reproducibility tests, the analyzed real-time PCR products were identified by electrophoresis bands.

All PCR reactions aimed to evaluate the sensitivity, specificity, and reproducibility of the real-time assays were performed in triplicate.

\section{MultiNA}

A qualitative assay was used to analyze the electrophoresis bands. MultiNA (Shimadzu Biotech., Japan) can be observed separated bands according to size. The electrophoresis bands of the real-time PCR assay samples were identified using the same method as normal PCR. In order to use a fluorescent solution, 10,000×concentrated SYBR Gold (Invitrogen, MOP-S-11494) was diluted to 1/ 100 using TE buffer solution (Promega, V6231), vortexmixed, and then diluted again to 1/100. A DNA-1000 kit was used as a Ladder marker. PhiX174 DNA Hae III Markers (Promega, G1761) were prepared after dilution to $1 / 100$. Five $\mu \mathrm{L}$ of PCR assay sample was injected into the well.

\section{Quantitative assay}

A quantitative real-time PCR assay for detection and quantification of cow milk in goat milk was developed. Certain proportions of cow milk were mixed with goat milk, PCR was performed, the relative quantity of expression of bovine mitochondrial $12 \mathrm{~S}$ rRNA-gene was determined, and a standard curve was plotted. The regression equation was calculated as $\mathrm{Y}=5.8926 \mathrm{X}-4.7976$ and the regression constant $\mathrm{R}^{2}$ value was 0.9914 . Also, purchased samples were examined using the same method, where cow-specific PCR was performed, relative expression levels were assayed, and mixture rates of bovine milk were determined using the standard curve. The detection limit of the method was determined by agarose gel electrophoresis of the amplification products obtained from both experimental mixtures, containing $0.1-100 \%$ of cow milk in goat milk.

\section{Results and Discussion}

\section{DNA content of samples}

The DNA contents of samples are shown in Table 2. The DNA contents of the raw milk, market milk, and infant formula were different due to adapted processing technology. The DNA content of the raw milk was higher than that of the market milk or infant formula. It is assumed that some factors like heat, drying, and treatment conditions could have affected the quantity of protein and DNA.

Table 2. Amount of DNA isolated from cow milk and goat milk

\begin{tabular}{|c|c|c|c|c|}
\hline & $260 \mathrm{~nm}$ & $280 \mathrm{~nm}$ & $260 / 280 \mathrm{~nm}$ & $\begin{array}{c}\text { DNA amount } \\
(\mathrm{ng} / \mu \mathrm{L})\end{array}$ \\
\hline \multicolumn{5}{|c|}{ Standard milk } \\
\hline Raw cow milk & 0.257 & 0.188 & 1.37 & $12.84 \pm 0.04$ \\
\hline Raw goat milk & 0.247 & 0.189 & 1.31 & $12.40 \pm 0.18$ \\
\hline \multicolumn{5}{|c|}{ Commercial goat dairy products } \\
\hline Liquid goat milk & 0.168 & 0.132 & 1.27 & $8.30 \pm 0.24$ \\
\hline Goat milk powder A & 0.146 & 0.124 & 1.18 & $7.27 \pm 0.17$ \\
\hline Goat milk powder B & 0.198 & 0.136 & 1.46 & $9.81 \pm 0.18$ \\
\hline Goat milk powder $\mathrm{C}$ & 0.161 & 0.115 & 1.40 & $8.00 \pm 0.54$ \\
\hline
\end{tabular}

Values are mean \pm SD.

\section{Real-time PCR}

\section{Cow-specific TaqMan real-time PCR}

Real-time PCR was performed for the mitochondrial $12 \mathrm{~S}$ rRNA-gene of cow milk and the specific primer 12STAQMANBT. The initial concentration of DNA template was diluted continuously from $20 \mathrm{ng}$ to $0.0002 \mathrm{ng}$. As a result, the fluorescence intensity increased with increasing PCR cycles (Fig. 1). The Ct values decreased quantitatively and reversed proportionally with the contents of the initial substances, respectively.

The electrophoresis results of the cow-specific PCR products are shown in Fig. 2. Bands were observed at 252 bp in all analyzed products of polymerase-reacted cow mitochondrial 12S rRNA, while no bands appeared for the raw goat milk and negative control samples. The electrophoresis band intensity decreased with decreasing fluorescent intensity of the plateau stage on the fluorescence curve (Fig. 1 and Fig. 2).

\section{Goat-specific TaqMan real-time PCR}

Real-time PCR was performed for the mitochondrial $12 \mathrm{~S}$ rRNA-gene of raw goat milk and the goat-specific primer 12STAQMANCH. The initial concentration of DNA template was diluted continuously from $20 \mathrm{ng}$ to $0.0002 \mathrm{ng}$, the same as for cow milk. The fluorescence 


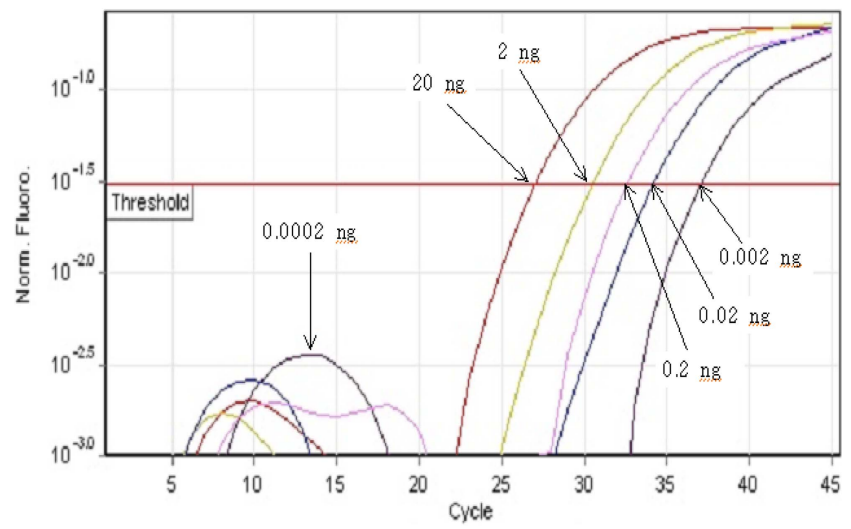

Fig. 1. Fluorescent profiles of PCR products amplified in the cow-specific TaqMan PCR using a decimal dilution series of raw cow milk DNA, plotted against cycle number. TaqMan PCR was applied: an initial hold step at $50^{\circ} \mathrm{C}$ for $2 \mathrm{~min}$ and pre-denaturation at $95^{\circ} \mathrm{C}$ for $10 \mathrm{~min}$, followed by 45 cycles with denaturationof at $95^{\circ} \mathrm{C}$ for 15 $\mathrm{s}$ and annealing at $60^{\circ} \mathrm{C}$ for $1 \mathrm{~min}$ and extension at $72^{\circ} \mathrm{C}$ for $15 \mathrm{~s}$.

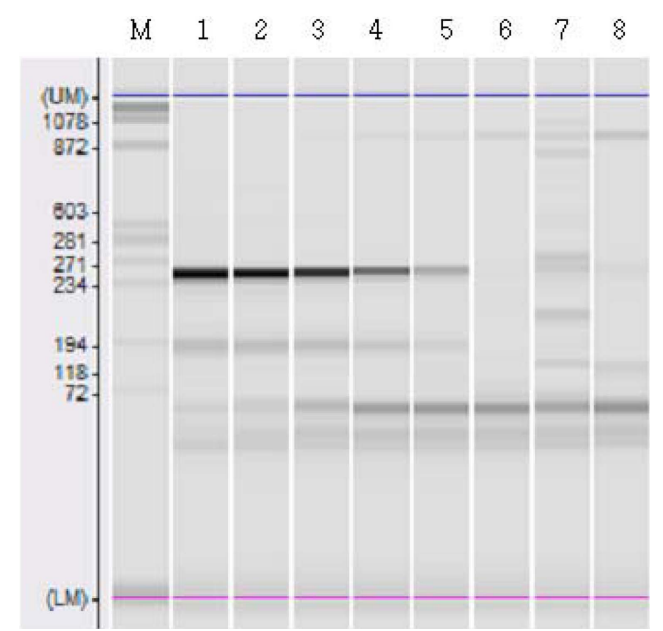

Fig. 2. Microchip electrophoresis images of cow-specific TaqMan PCR amplified products isolated DNA from raw cow milk. Lane M, DNA size marker; lane 1, raw cow milk DNA of $20 \mathrm{ng}$; lane 2, $2 \mathrm{ng}$; lane 3, $0.2 \mathrm{ng}$; lane 4, $0.02 \mathrm{ng}$; lane 5, $0.002 \mathrm{ng}$; lane 6, $0.0002 \mathrm{ng}$ and lane 7, raw goat milk DNA $10 \mathrm{ng}$; lane 8 , negative control

intensity of samples decreased with increasing PCR cycle number, while the threshold $\mathrm{Ct}$ value decreased reverseproportionally to the initial substrate quantity (Fig. 3).

The electrophoresis results of the assayed products after goat-specific PCR are shown in Fig. 4. The band of the PCR assayed $12 \mathrm{~S}$ rRNA of the goat milk was identified at $171 \mathrm{bp}$, but no bands appeared for the raw cow milk and negative control (Fig. 4).

\section{Mammalian-specific TaqMan real-time PCR}

Real-time PCR was performed for the mitochondrial

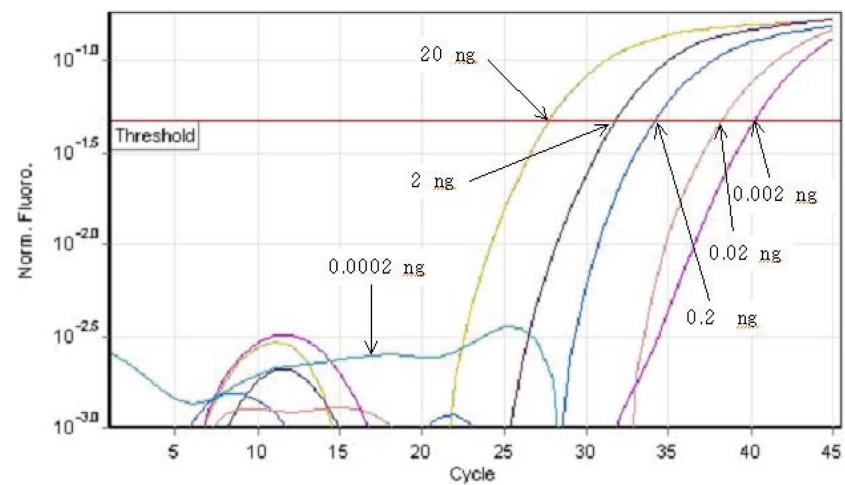

Fig. 3. Fluorescent profiles of PCR products amplified in the goat-specific TaqMan PCR using a decimal dilution series of raw goat milk DNA, plotted against cycle number. TaqMan PCR was applied: an initial hold step at $50^{\circ} \mathrm{C}$ for $2 \mathrm{~min}$ and pre-denaturation at $95^{\circ} \mathrm{C}$ for $10 \mathrm{~min}$, followed by 45 cycles with denaturation of at $95^{\circ} \mathrm{C}$ for 15 $\mathrm{s}$ and annealing at $60^{\circ} \mathrm{C}$ for $1 \mathrm{~min}$ and extension at $72^{\circ} \mathrm{C}$ for $15 \mathrm{~s}$.

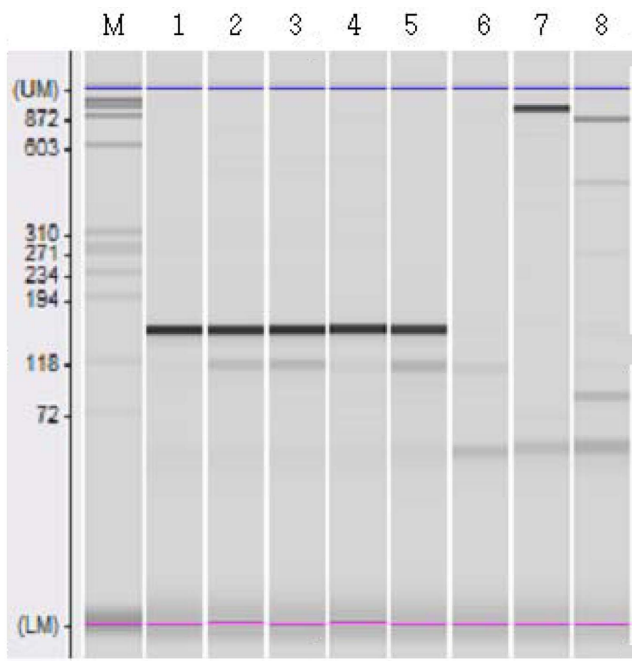

Fig. 4. Microchip electrophoresis images of goat-specific TaqMan PCR amplified products and isolated DNA from raw goat milk. Lane $M$, DNA size marker; lane 1, raw goat milk DNA of $20 \mathrm{ng}$; lane 2, $2 \mathrm{ng}$; lane 3, $0.2 \mathrm{ng}$; lane 4, $0.02 \mathrm{ng}$; lane 5, $0.002 \mathrm{ng}$; lane 6, $0.0002 \mathrm{ng}$ and lane 7, raw cow milk DNA $10 \mathrm{ng}$; lane 8 , negative control

$12 \mathrm{~S}$ rRNA-gene of cow milk and the mammalian-specific primer 12STAQMANREVM2. The initial concentration of DNA template was diluted continuously from $20 \mathrm{ng}$ to $0.0002 \mathrm{ng}$. The fluorescence intensity of samples increased with increasing PCR cycle number, while the threshold $\mathrm{Ct}$ values of $20 \mathrm{ng}, 2 \mathrm{ng}$, and $0.2 \mathrm{ng}$ decreased reverseproportionally to the initial substrate quantity. The threshold $\mathrm{Ct}$ values of $0.02 \mathrm{ng}, 0.002 \mathrm{ng}$, and $0.0002 \mathrm{ng}$ increased almost the same (Fig. 5). The applied internal standard material for the mammalian-specific primer was somewhat inferior to the cow- or goat-specific primer. 
The electrophoresis results of the assayed products after mammalian-specific PCR are shown in Fig. 6. The bands of the PCR assayed 12S rRNA of the raw cow milk and raw goat milk were identified at $119 \mathrm{bp}$, but no band appeared for the negative control.

\section{Reliability of real-time PCR}

It was verified that the $12 \mathrm{~S}$ rRNA gene of raw milk species allowed for the possible quantitative measure of

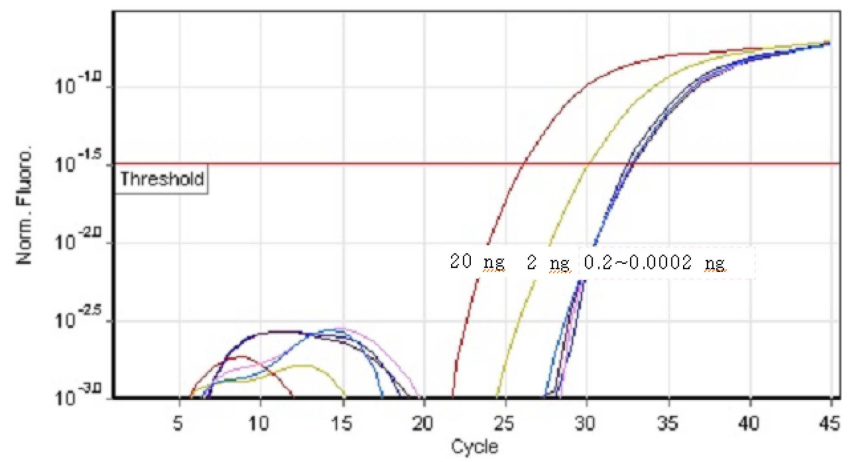

Fig. 5. Fluorescent profiles of PCR products amplified in the mammalian-specific TaqMan PCR using a decimal dilution series of raw cow milk DNA, plotted against cycle number. TaqMan PCR was applied: an initial hold step at $50^{\circ} \mathrm{C}$ for $2 \mathrm{~min}$ and pre-denaturation at $95^{\circ} \mathrm{C}$ for 10 min, followed by 45 cycles with denaturation at $95^{\circ} \mathrm{C}$ for $15 \mathrm{~s}$ and annealing at $60^{\circ} \mathrm{C}$ for $1 \mathrm{~min}$ and extension at $72^{\circ} \mathrm{C}$ for $15 \mathrm{~s}$.

the level of gene expression up to $2 \mathrm{pg}$. From the results of cow-specific real-time PCR, a detection level of the cow milk mixture ratio of up to $0.1 \%$ seemed to be possible (Fig. 4 and Fig. 7). The electrophoresis results showed bands for the $0.1 \%$ mixture at $252 \mathrm{bp}$, and the intensity of bands appeared stronger with increasing mixing ratios of cow milk. Lopez-Calleja et al. (2007a) reported that a detection level of $0.5 \%$ of bovine milk in a ewe milk mixture was possible by real-time PCR assay.

As a result of the polymerase reaction, the $12 \mathrm{~S}$ rRNA and 12STAQMANBT of bovine milk, and 12S rRNA and 12STAQMANCH of goat milk, showed increasing fluorescent curves, while the negative control sample showed no increasing tendency. The Ct-values of cow-specific and goat-specific PCR were $25.5 \pm 0.7$ and $40.3 \pm 0.9$, respectively, while the goat-specific Ct-values were $36.8 \pm 1.2$ and 23.0 \pm 0.6 , respectively. The expression levels of mammalian-specific PCR were $24.2 \pm 0.5$ for cow milk and $25.5 \pm 0.5$ for goat milk.

From the electrophoresis results of the assayed products after mammalian-specific PCR, a band appeared for the

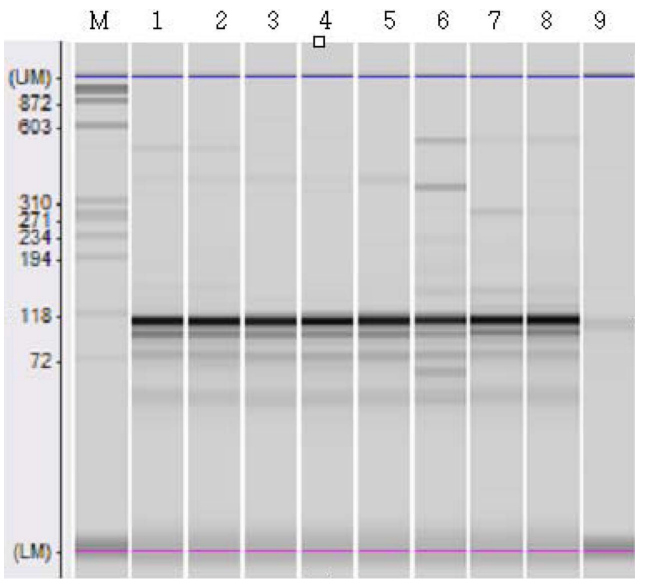

Fig. 6. Microchip electrophoresis images of mammalian-specific TaqMan PCR amplified products and isolated DNA from raw cow milk. Lane $M$, DNA size marker; lane 1, cow DNA of $20 \mathrm{ng}$; lane 2, $2 \mathrm{ng}$; lane 3, $0.2 \mathrm{ng}$; lane 4, $0.02 \mathrm{ng}$; lane 5, $0.002 \mathrm{ng}$; lane 6, $0.0002 \mathrm{ng}$ and lane 7, raw cow milk DNA $10 \mathrm{ng}$; lane 8, raw goat milk DNA 10 ng, lane 9; negative control.

12S rRNA of the PCR assayed positive control milk, while the crosslinked 12S rRNA and negative control did not show bands.

Lopez-Calleja et al. (2007a) performed real-time PCR using 12SM-FW/12SBT-RV primers and concluded that only bovine milk showed an increasing fluorescent curve and verified its specificity. The results of real-time PCR showed cow-specific and goat-specific plateaus coincident to the results of electrophoresis. It can be assumed that real-time PCR has the ability to quantify through threshold cycle numbers $(\mathrm{Ct})$ as precise as possible.

According to the results, the raw goat milk and goat milk powder B did not show electrophoresis bands, but the goat milk and goat milk powders $\mathrm{A}$ and $\mathrm{C}$ showed bands at 252 bp. It is assumed that this was due to the cow milk gene being mixed into the goat milk and modified goat milk powder.

\section{Quantitative assay}

In order to establish a precise method for quantitative measurement of cow milk in cow- and goat milk mixtures, expression levels of mixtures along with samples using mammalian-specific primer as an internal standard were applied. The mark points for cow milk detection in real-time PCR were $252 \mathrm{bp}$ for the cow mitochondrial 12S rRNA gene (Lopez-Calleja et al., 2007a), and 119 bp for the mammalian gene similar to cow as well as the goat and buffalo 12S rRNA gene (Lopez-Calleja et al., 2007b). The use of internal standard substances is important, because it is considered to affect factors of the DNA 
Table 3. Relative quantitation of Cow 12S rRNA and threshold cycles (Ct) in cow-specific TaqMan PCR with 10 ng DAN isolated commercial goat dairy products

\begin{tabular}{|c|c|c|c|c|c|c|}
\hline & \multicolumn{2}{|c|}{ "Mammalian-specific PCR } & \multicolumn{2}{|c|}{ "Cow-specific PCR } & \multirow{2}{*}{ Correction } & \multirow{2}{*}{ Relative quantify } \\
\hline & Threshold cycles & Calc. conc. ${ }^{1)}$ & Threshold cycles & Calc. conc. & & \\
\hline \multicolumn{7}{|c|}{ Mixture \% (cow milk in goat milk) } \\
\hline 0.1 & 24.19 & 97.501 & 35.23 & 0.039 & 0.0004 & 1.000 \\
\hline 0.5 & 24.25 & 93.361 & 34.24 & 0.076 & 0.0008 & 2.052 \\
\hline 1 & 24.76 & 64.564 & 33.43 & 0.132 & 0.0020 & 5.155 \\
\hline 5 & 24.28 & 91.357 & 31.15 & 0.625 & 0.0068 & 17.250 \\
\hline 10 & 24.24 & 94.038 & 29.74 & 1.634 & 0.0174 & 43.842 \\
\hline 20 & 24.11 & 103.308 & 28.21 & 4.639 & 0.0449 & 113.307 \\
\hline 30 & 24.24 & 94.038 & 27.70 & 6.570 & 0.0699 & 176.260 \\
\hline \multicolumn{7}{|c|}{ Commercial goat dairy products } \\
\hline Liquid goat milk & 24.38 & 84.983 & 32.92 & 0.187 & 0.0022 & 5.545 \\
\hline Goat milk powder $\mathrm{A}$ & 28.21 & 5.327 & 33.71 & 0.109 & 0.0205 & 51.618 \\
\hline Goat milk powder B & 24.41 & 83.160 & - & - & - & - \\
\hline Goat milk powder $\mathrm{C}$ & 24.75 & 65.032 & 29.74 & 1.634 & 0.0251 & 63.396 \\
\hline
\end{tabular}

${ }^{1)}$ Calc. conc., Calculated concentration

polymerase reaction (Lopez-Calleja et al., 2007a).

The intensity of the plateau was almost the same and the electrophoresis bands of the PCR products of mixtures appeared as $119 \mathrm{bp}$.

The Ct values of mixtures and goat milk powder ranged from 24.11 to 35.23 and showed similar expression levels, where the $\mathrm{Ct}$ value of sample $\mathrm{A}$ was the lowest at 28.21 (Table 3). The $\mathrm{Ct}$ values of mixtures and samples after cow-specific PCR decreased as the quantity of cow milk increased in the mixture as shown in Table 3. The

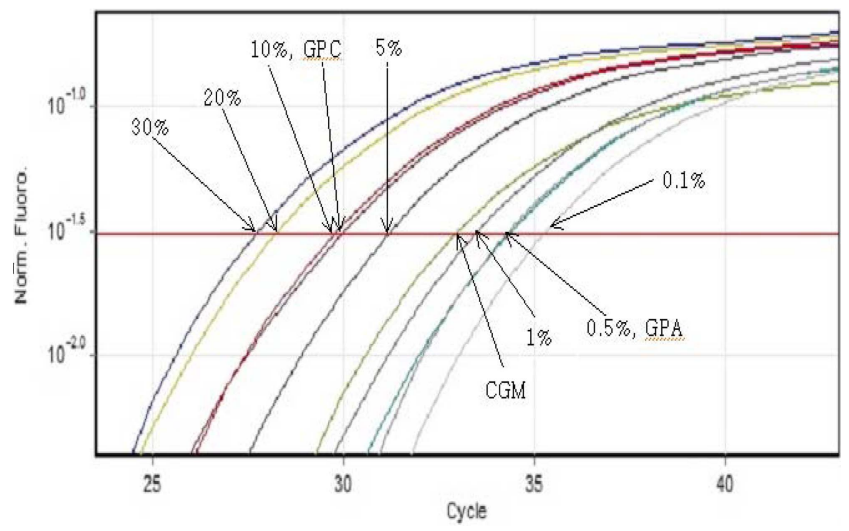

Fig. 7. Fluorescent profiles of PCR products amplified in the cow-specific TaqMan PCR analysis from cow/goat milk binary mixtures (cow milk $0.1 \%, 0.5 \%, 1 \%, 5 \%$, $10 \%, 20 \%$, and $30 \%$ in goat milk) and commercial dairy product DNA, plotted against cycle number. TaqMan PCR was applied: an initial hold step at $50^{\circ} \mathrm{C}$ for $2 \mathrm{~min}$ and pre-denaturation at $95^{\circ} \mathrm{C}$ for $10 \mathrm{~min}$, followed by 45 cycles with denaturation at $95^{\circ} \mathrm{C}$ for $15 \mathrm{~s}$ and annealing at $60^{\circ} \mathrm{C}$ for $1 \mathrm{~min}$ and extension at $72^{\circ} \mathrm{C}$ for 15 s. CGM, commercial liquid goat milk; GPA, commercial goat milk powder A; GPC, commercial goat milk powder C. increase in the fluorescence curve identified the $0.1 \%$ mixture (Fig. 7).

The electrophoresis results of the PCR products showed bands at $252 \mathrm{bp}$, which identified that the 12S rRNA gene was polymerized in all mixtures (Fig. 8).

Table 3 shows the relative expression values of specific genes against cow milk using correction values through mixtures and samples against the mammalian specific gene. The specific gene expression values from relative quantitative assays of the mixtures $(0.1 \%, 0.5 \%, 1 \%, 5 \%$,

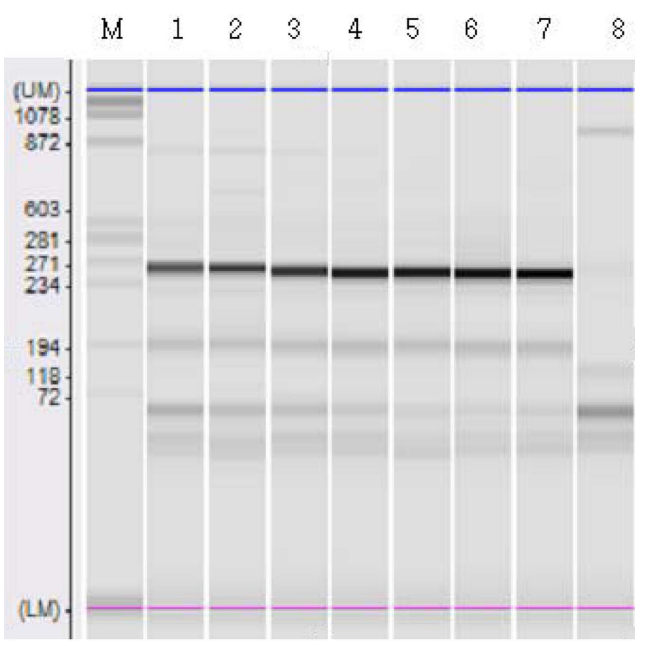

Fig. 8. Microchip electrophoresis images of cow-specific TaqMan PCR amplified products and isolated DNA from cow/goat milk binary mixtures (cow $0.1 \%, 0.5 \%, 1 \%$, $5 \%, \mathbf{1 0} \%, \mathbf{2 0} \%$, and $30 \%$ in goat). Lane $M$, DNA size marker; lane 1, 0.1\%; lane 2, 0.5\%; lane 3, $1 \%$; lane 4 , $5 \%$; lane 5, 10\%; lane 6, 20\%; lane 7, 30\%; lane 8, negative control. 
$10 \%, 20 \%$, and $30 \%$ ) were acquired by plotting the standard curve, in which the regression equation was $\mathrm{Y}=$ 5.8926X-4.7976, and $\mathrm{R}^{2}=0.9914$.

The relative expression values of the cow mitochondrial 12S rRNA gene from market goat milk were: 5.545 in liquid goat milk, 51.618 in modified goat milk powder A, and 63.40 in modified goat milk powder C (Table 3). In this way, the mixed amount of cow milk was measured with expression values of samples using the standard curves of expression values of the mixtures. From the results, there was $1.8 \%$ cow milk detected in the purchased liquid goat milk, $9.6 \%$ in the modified goat milk powder $\mathrm{A}, 11.6 \%$ in the modified goat milk powder $\mathrm{C}$, and $0.0 \%$ in the modified goat milk powder $\mathrm{B}$, respectively.

\section{Acknowledgements}

This study was financially supported by the Special Research Program of Chonnam National University, 2009. We thank Rainbow Goat Milk Farm, Imsil-Gun, Korea for generous donation of the raw goat milk used in this study.

\section{References}

1. Anguita, G., Martin, R., Garcia, T., Morales, P., Haza, A., and Gonzalez, I. (1997) A competitive enzyme-linked immunosorbent assay for detection of bovine milk in ovine and caprine milk and cheese using a monoclonal antibody against bovine $\beta$-casein. J. Food Prot. 60, 64-66.

2. Bottero, M. T., Civera, T., Nucera, D., Rosati, S., Sacchi, P., and Turi, R. M. (2003) A multiplex polymerase chain reaction for the identification of cows', goats' and sheeps' milk in dairy products. Int. Dairy J. 13, 277-282.

3. Chianese, L., Laezza, P., Smaldone, L. A., Stingo, C., Del Giovine, L., and Addeo, F. (1990) Evaluation of bovine milk in the buffalo mozzarella cheese by two-dimensional electrophoresis. Scienza e Tecnica Lattiero Casearia 41, 315-326.

4. Hurley, I. P., Ireland, H. E., Coleman, R. C., and Williams, J. H. H. (2004) Application of immunological methods for the detection of species adulteration in dairy products. Int. $J$. Food Sci. Technol. 39, 873-878.

5. Kotowicz, M., Adamczyk, E., and Bania, J. (2007) Application of a duplex-PCR for detection of cow's milk in goats' milk. Ann. Agric. Environ. 14, 215-218.

6. Lee, S. B. and Choi, S. H. (2009) Rapid identification of cow and goat milk in milk products using a duplex PCR Technique. Korean J. Food Sci. Ani. Resour. 29, 647-652.

7. López-Calleja, I., González, I., Fajardo, V., Rodríguez, M. A., Hernández, P. E., García, T. and Martín, R. (2005) PCR detection of cows' milk in buffalo milk and mozzarella cheese. Int. Dairy J. 15, 1122-1129.

8. López-Callejaa, I., González, I., Fajardoa, V., Martína, I.,
Hernándeza, P. E., García, T. and Martín, R. (2007a) Realtime TaqMan PCR for quantitative detection of cows' milk in ewes' milk mixtures. Int. Dairy J. 17, 729-736.

9. López-Calleja, I., González, I., Fajardo, V., Rodríguezn M. A., Hernández, P. E., García T., and Martín, R. (2007b) Quantitative detection of goats' milk in sheep's milk by realtime PCR. Food Control 18, 1466-1473.

10. Lopparelli, R. M., Cardazzo, B,. Balzan, S., Giaccone, V., and Novelli, E. (2007) Real-time TaqMan polymerase chain reaction detection and quantification of cow DNA in pure water buffalo mozzarella cheese: method validation and its application on commercial samples. J. Agric. Food Chem. 55, 3429-3434.

11. Madani, M., Subbotin, S. A., and Moens, M. (2005) Quantitative detection of the prtato cyst nematode, Globodera pallida, and the beer xyst nematode, Heterodera schachtii, using real-time PCR with SYBR green I dye. Mol. Cell. Probes 19, 81-86.

12. Mafra, I., Ferreira, I., Beatriz, M., and Oliveira,. P. P. (2004) Food authentication by PCR-based methods. Eur. Food Res. Technol. 227, 649-665.

13. Mafra, I., Ferreira, I., Faria, M. A., and Oliveira, P. P. (2008) A novel approach to the quantification of bovine milk in ovine cheeses using a duplex polymerase chain reaction method. J. Agric. Food Chem. 52, 4943-4947.

14. Martinez, N., Martin, M. C., Herrero, A., Fernandez, M., Alvarez, M. A., and Ladero, V. (2011) qPCR as a powerful tool for microbial food spoilage quantification: Significance for food quality. Trends Food Sci. Technol. 22, 367-376.

15. Mayer, H. K., Heidler, D., and Rockenbauer, C. (1997) Determination of the percentages of cows', ewes' and goats' milk in cheese by isoelectric focusing and cation-exchange HPLC of $\gamma$-and para-K-casein. Int. Dairy J. 7, 619-628.

16. Mayer, H. K. (2005) Milk species identification in cheese varieties using electrophoretic, chromatographic and PCR techniques. Int. Dairy J. 15, 595-604.

17. McCane, Widdowson, Scherz, and Kloos (2007) Milk analysis. North Wales Buffalo. Archived from the original on 2007-09-29.

18. Mininni, A. N., Pellizzari, C., Cardazzo, B., Carraro, L., Balzan, S., and Novelli, E. (2009) Evaluation of real-time PCR assays for detection and quantification of fraudulent addition of bovine milk to caprine and ovine milk for cheese manufacture. Int. Dairy J. 19, 617-623.

19. Moio, L., Sasso, M. L., Chianese, L., and Addeo, F. (1990) Rapid detection of bovine milk in ovine, carprine and water buffalo milk or cheese by gel isoelectric focusing on PhastSystem. Italian J. Food Sci. 3, 185-191.

20. Molina, E., Martin-Alvarez, P. J., and Ramos, M. (1999) Analysis of cows', ewes' and goats' milk mixtures by capillary electrophoresis quantification by multivariate regression analysis. Int. Dairy J. 9, 99-105.

21. Takara Korea Biomedical Inc. (2007) Introduction of real time PCR. Seoul, Korea, pp. 62-65. 